\title{
Results of Replantation of 33 Ring Avulsion Amputations
}

\author{
Roberto Adani, MD, Elisabetta Pataia, MD, Luigi Tarallo, MD, Raffaele Mugnai, MD
}

Purpose Despite microsurgical advances, it is still difficult to achieve satisfactory functional results in cases of replantations following complete ring avulsion amputations. Our aim is to report the experience we have collected since the early 1990s in the treatment of this type of injury.

Methods We replanted 33 fingers on 33 patients (age, 15-54 y) with complete ring avulsion amputation injuries. Twenty-eight amputations were distal to the insertion of the flexor digitorum superficialis, and 5 were complete degloving injuries with intact tendons. Vascular transpositions and vein grafts were used, and in all cases, only 1 of the digital nerves was repaired.

Results The 29 successful cases were tracked over an average follow-up of 89 months. The average total active motion of the reconstructed finger was $185^{\circ}$. Sensibility evaluated by static 2-point discrimination varied from 9 to $15 \mathrm{~mm}$ and by moving 2-point discrimination from 8 to $15 \mathrm{~mm}$. Five patients complained of cold intolerance.

Conclusions Resection of the avulsed digital artery and vein is the most crucial part of the procedure. Vessels reconstruction can be performed using various methods, but vessel transfers from the middle finger appear to be the most reliable solution. The outcome of the cases demonstrates that replantation should be attempted. (J Hand Surg 2013;38A:947-956. Copyright (C) 2013 by the American Society for Surgery of the Hand. All rights reserved.) Type of study/level of evidence Therapeutic IV.

Key words Ring injuries, complete amputation, degloving injury, vessel transfer, replantation.

$\mathrm{R}$ ING AVULSION INJURIES continue to be a challenge for reconstructive surgeons. ${ }^{1}$ These injuries are usually caused by crushing, shearing, and avulsing the soft tissue envelope, ${ }^{2}$ resulting in severe macroscopic and microscopic damage to the digital vessels and nerves. ${ }^{3}$

Despite microsurgical advances, it is still difficult to

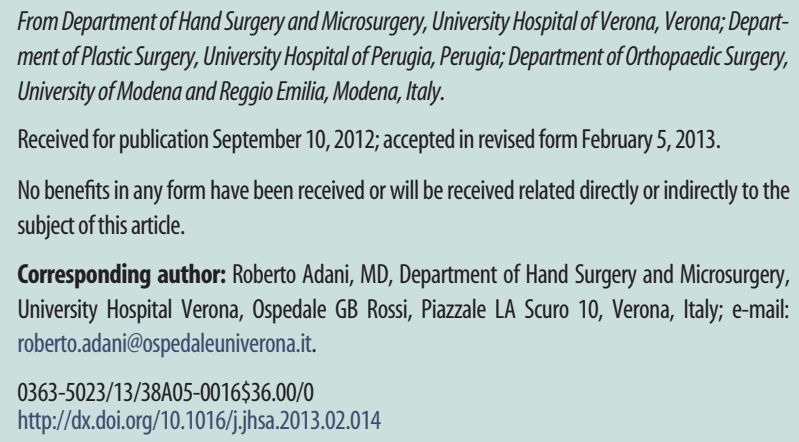

achieve satisfactory functional results in complete ring degloving injuries and amputations. Controversy continues regarding whether or not replantation or revision of the amputation should be performed. ${ }^{4-10}$ Most hand surgeons would not advocate replanting single-finger amputations, ${ }^{8}$ especially in cases of complete degloving. ${ }^{4,6}$ Even with a successful revascularization of the skin, a risk remains of poor functional results ${ }^{7}$ that may interfere with overall hand function.

Various classification systems have been proposed. ${ }^{4,5,11-13}$ The most commonly accepted classification was published in the early 1980s by Urbaniak et al ${ }^{4}$ that divided the injuries into 3 classes according to the circulatory status. In 1989 , Kay et $\mathrm{al}^{11}$ proposed an alternative classification that is a prognostic system including injuries with or without skeletal injuries. In 1996, Adani et al ${ }^{12}$ modified the Kay et al classification by including degloving ring injuries in class IV and also 
by dividing the complete amputation category into 2 subgroups to distinguish amputations distal to the flexor digitorum superficialis (FDS) insertion from those proximal to the FDS insertion.

The purposes of this article are to report the experiences we have collected since the early 1990s of the treatment of complete degloving and amputation ring injuries, to conduct a review of the English literature about ring avulsion injuries, and to define the most appropriate technique for restoring circulation.

\section{MATERIALS AND METHODS}

In this retrospective cohort study, we reviewed all the ring amputation injuries treated from January 1990 to January 2010 (minimum 1-year follow-up). To identify patients and to define and classify the ring injury, we reviewed hospital records, x-rays, electronic databases containing all the operations performed, and file images (including before and after surgery and follow-up). The inclusion criteria were ages from 14 to 60 years old and with complete ring finger amputations. Patients with systemic diseases such as diabetes mellitus, vascular disease, alcohol abuse, and heavy smoking histories were excluded.

Thirty-nine patients with class IV injuries according to the Kay et al classification were identified. In our study, we subdivided class IV injuries into 3 groups:

- Amputation distal to the insertion of FDS (class IVd injuries: 28 cases),

- Amputation proximal to the FDS insertion (class IVp injuries: 6 cases), and

- Complete degloving injuries with intact tendons (class IVi injuries: 5 cases).

Replantation was done in class IVi and class IVd injuries (33 cases; 23 male, 10 female). The average patient age was 36 years (range, 14-54 y).

Microsurgical repair was performed using axillary block anesthesia. In cases of class IVi, the degloved soft tissue envelope was everted, allowing exploration of the digital arteries and veins. A midlateral line incision was made on the side of the degloved skin that had the most suitable vessel for revascularization. In the class IVd, a midlateral incision in the amputated finger was made in order to observe the neurovascular bundles. The choice of whether to make the incision on the ulnar or radial side depended on the skin condition of the amputated finger. The recipient artery was carefully dissected under the microscope until a normal appearance of the lumen of the digital artery was found. With the help of subcutaneous hematomas on the dorsal surface of the digit, we were able to find the site of vein disruption, and a dorsal incision was routinely performed. The surgical approach to the ring finger was obtained volarly through a zig-zag Bruner incision and dorsally through a longitudinal incision.

Before performing artery transfer, it was necessary to carry out a digital Allen test to the middle finger. The surgical approach was done using a Bruner incision. The ulnar artery was dissected from the metacarpophalangeal (MCP) joint level to the distal interphalangeal (DIP) joint level of the middle finger. The isolated digital artery was first identified and then separated from the digital nerve, preserving as much fibrofatty tissue around the nerve as possible to avoid injury or devascularization of the digital nerve. The ulnar digital artery of the middle finger was transferred to the ring finger by means of a subcutaneous tunnel to reduce further scars in the ring finger and to avoid the proximal incision at the base of the ring finger. Primary arterial suturing was never performed.

In 15 patients, we used vein grafts taken from the volar aspect of the wrist to bridge segmental digital arterial injuries. In 18 patients, the ulnar digital artery of the middle finger was transferred to the ring finger. In 20 patients, direct venous anastomosis was performed. Vein grafts were used for 12 patients, and a vein was transferred from the dorsum of the middle finger in 12 patients. At least 2 veins were always restored (Table 1).

Direct nerve repair was performed in 8 patients. In 16 patients, the proximal stump of the radial digital nerve was transposed and repaired on the distal stump of the ulnar digital nerve. In 5 patients, 1 digital nerve was reconstructed using a graft from the other digital nerve. In 2 patients, 1 nerve was reconstructed with a vein graft. In 2 patients, no nerve reconstruction was performed. In all cases, only 1 of the digital nerves was repaired (Table 1).

Extensor tendons were sutured in 9 cases (class IVd), and the flexor digitorum profundus was never repaired. The FDS always remained intact along with a preserved proximal interphalangeal (PIP) joint.

Arthrodesis of the DIP joint was done using K-wires when amputation went through the joint (25 cases of class IVd). When the amputation was at the middle phalanx level ( 3 cases of class IVd), the phalanx was fixed with $\mathrm{K}$-wires. The degloved skin envelope was fixed to the tip of the distal phalanx using a K-wire in class IVi cases.

After surgery, the patients were put on a lowmolecular-weight dextran $(500 \mathrm{~mL} / \mathrm{d})$ for 7 days and oral aspirin $(250 \mathrm{mg} / \mathrm{d})$ for 30 days. Prophylactic widespectrum antibiotics were administered for 5 days. All 


\section{TABLE 1. Subjects' Characteristics, Type of Injury, Surgical Procedure, and Clinical Outcome}

\begin{tabular}{|c|c|c|c|c|c|c|c|c|c|c|}
\hline \multirow[b]{2}{*}{ Patient } & \multirow[b]{2}{*}{ Sex } & \multirow[b]{2}{*}{ Age (y) } & \multirow[b]{2}{*}{ Class } & \multirow[b]{2}{*}{ Surgical Procedure } & \multirow[b]{2}{*}{ Complication } & \multirow[b]{2}{*}{ Result } & \multirow{2}{*}{$\begin{array}{l}\text { Follow-Up } \\
\qquad(\mathrm{mo})\end{array}$} & \multirow[b]{2}{*}{ TAM } & \multicolumn{2}{|c|}{ Sensibility } \\
\hline & & & & & & & & & $2 \mathrm{sPD}$ & $2 \mathrm{mPD}$ \\
\hline 1 & $\mathrm{~F}$ & 27 & IVi & $\begin{array}{l}\text { A: } 1 \text { Transfer } \\
\text { V: } 1 \text { Graft }+1 \text { transfer } \\
\text { N: Cross }\end{array}$ & I & Success & 235 & 240 & 10 & 8 \\
\hline 2 & M & 21 & IVi & $\begin{array}{l}\text { A: } 1 \text { Transfer } \\
\text { V: } 1 \text { Direct }+1 \text { transfer } \\
\text { N: Cross }\end{array}$ & I & Success & 184 & 205 & 9 & 8 \\
\hline 3 & $\mathrm{~F}$ & 35 & IVi & $\begin{array}{l}\text { A: } 1 \text { Transfer } \\
\text { V: } 2 \text { Transfers } \\
\text { N: No repair }\end{array}$ & I & Success & 146 & 190 & 15 & 15 \\
\hline 4 & M & 28 & IVi & $\begin{array}{l}\text { A: } 1 \text { Graft } \\
\text { V: } 2 \text { Transfers } \\
\text { N: Graft }\end{array}$ & I & Success & 82 & 185 & 13 & 11 \\
\hline 5 & M & 43 & IVi & $\begin{array}{l}\text { A: } 1 \text { Transfer } \\
\text { V: } 2 \text { Transfers } \\
\text { N: Cross }\end{array}$ & I & Success & 48 & 210 & 12 & 10 \\
\hline 6 & $\mathrm{M}$ & 26 & IVd & $\begin{array}{l}\text { A: } 1 \text { Graft } \\
\text { V: } 2 \text { Direct } \\
\text { N: Direct ulnar }\end{array}$ & I & Success & 220 & 180 & 9 & 8 \\
\hline 7 & M & 38 & IVd & $\begin{array}{l}\text { A: } 1 \text { Transfer } \\
\text { V: } 1 \text { Direct }+1 \text { graft } \\
\text { N: Cross }\end{array}$ & l & Success & 191 & 170 & 12 & 10 \\
\hline 8 & $\mathrm{~F}$ & 49 & $\mathrm{IVd}$ & $\begin{array}{l}\text { A: } 1 \text { Graft } \\
\text { V: } 2 \text { Direct } \\
\text { N: Cross }\end{array}$ & I & Success & 169 & 165 & 14 & 11 \\
\hline 9 & $\mathrm{M}$ & 19 & IVd & $\begin{array}{l}\text { A: } 1 \text { Graft } \\
\text { V: } 2 \text { Direct } \\
\text { N: Cross }\end{array}$ & I & Success & 152 & 195 & 12 & 10 \\
\hline 10 & $\mathrm{M}$ & 51 & IVd & $\begin{array}{l}\text { A: } 1 \text { Graft } \\
\text { V: } 1 \text { Direct }+1 \text { graft } \\
\text { N: Direct ulnar }\end{array}$ & I & Success & 132 & 185 & 11 & 8 \\
\hline 11 & M & 37 & IVd & $\begin{array}{l}\text { A: } 1 \text { Transfer } \\
\text { V: } 2 \text { Transfers } \\
\text { N: Nerve graft }\end{array}$ & I & Success & 131 & 195 & 15 & 13 \\
\hline 12 & $\mathrm{~F}$ & 40 & IVd & $\begin{array}{l}\text { A: } 1 \text { Transfer } \\
\text { V: } 2 \text { Transfers } \\
\text { N: Graft }\end{array}$ & Artery thrombosis & Failure & I & I & I & I \\
\hline 13 & $\mathrm{M}$ & 54 & IVd & $\begin{array}{l}\text { A: } 1 \text { Graft } \\
\text { V: } 2 \text { Grafts } \\
\text { N: No repair }\end{array}$ & $\begin{array}{l}\text { Artery and vein } \\
\text { thrombosis }\end{array}$ & Failure & I & / & l & I \\
\hline 14 & M & 27 & IVd & $\begin{array}{l}\text { A: } 1 \text { Graft } \\
\text { V: } 1 \text { Direct }+1 \text { graft } \\
\text { N: Direct radial }\end{array}$ & I & Success & 94 & 185 & 9 & 8 \\
\hline
\end{tabular}




\section{TABLE 1. Subjects' Characteristics, Type of Injury, Surgical Procedure, and Clinical Outcome (Continued)}

\begin{tabular}{|c|c|c|c|c|c|c|c|c|c|c|}
\hline \multirow[b]{2}{*}{ Patient } & \multirow[b]{2}{*}{ Sex } & \multirow[b]{2}{*}{ Age (y) } & \multirow[b]{2}{*}{ Class } & \multirow[b]{2}{*}{ Surgical Procedure } & \multirow[b]{2}{*}{ Complication } & \multirow[b]{2}{*}{ Result } & \multirow{2}{*}{$\begin{array}{l}\text { Follow-Up } \\
\quad(\mathrm{mo})\end{array}$} & \multirow[b]{2}{*}{ TAM } & \multicolumn{2}{|c|}{ Sensibility } \\
\hline & & & & & & & & & $2 \mathrm{sPD}$ & $2 \mathrm{mPD}$ \\
\hline 15 & M & 41 & $\mathrm{IVd}$ & $\begin{array}{l}\text { A: } 1 \text { Transfer } \\
\text { V: } 2 \text { Direct } \\
\text { N: Direct ulnar }\end{array}$ & I & Success & 91 & 170 & 11 & 9 \\
\hline 16 & M & 30 & $\mathrm{IVd}$ & $\begin{array}{l}\text { A: } 1 \text { Graft } \\
\text { V: } 1 \text { Direct }+1 \text { graft } \\
\text { N: Cross }\end{array}$ & 1 & Success & 85 & 165 & 12 & 10 \\
\hline 17 & $\mathrm{~F}$ & 47 & $\mathrm{IVd}$ & $\begin{array}{l}\text { A: } 1 \text { Transfer } \\
\text { V: } 2 \text { Transfers } \\
\text { N: Cross }\end{array}$ & Artery revision & Success & 79 & 195 & 13 & 11 \\
\hline 18 & $\mathrm{M}$ & 32 & $\mathrm{IVd}$ & $\begin{array}{l}\text { A: } 1 \text { Transfer } \\
\text { V: } 2 \text { Transfers } \\
\text { N: Cross }\end{array}$ & I & Success & 71 & 185 & 12 & 10 \\
\hline 19 & F & 52 & $\mathrm{IVd}$ & $\begin{array}{l}\text { A: } 1 \text { Transfer } \\
\text { V: } 1 \text { Direct }+1 \text { graft } \\
\text { N: Direct ulnar }\end{array}$ & I & Success & 66 & 160 & 10 & 8 \\
\hline 20 & M & 49 & IVd & $\begin{array}{l}\text { A: } 1 \text { Graft } \\
\text { V: } 1 \text { Direct }+1 \text { graft } \\
\text { N: Cross }\end{array}$ & $\begin{array}{l}\text { Artery and vein } \\
\text { thrombosis }\end{array}$ & Failure & l & I & I & I \\
\hline 21 & $\mathrm{~F}$ & 22 & IVd & $\begin{array}{l}\text { A: } 1 \text { Graft } \\
\text { V: } 2 \text { Direct } \\
\text { N: Direct ulnar }\end{array}$ & I & Success & 59 & 190 & 9 & 8 \\
\hline 22 & M & 45 & $\mathrm{IVd}$ & $\begin{array}{l}\text { A: } 1 \text { Transfer } \\
\text { V: } 2 \text { Transfers } \\
\text { N: Graft }\end{array}$ & I & Success & 55 & 180 & 15 & 13 \\
\hline 23 & M & 49 & IVd & $\begin{array}{l}\text { A: } 1 \text { Graft } \\
\text { V: } 1 \text { Direct }+1 \text { graft } \\
\text { N: Cross }\end{array}$ & $\begin{array}{l}\text { Artery and vein } \\
\text { thrombosis }\end{array}$ & Failure & I & / & I & I \\
\hline 24 & $\mathrm{~F}$ & 34 & $\mathrm{IVd}$ & $\begin{array}{l}\text { A: } 1 \text { Graft } \\
\text { V: } 2 \text { Direct } \\
\text { N: Cross }\end{array}$ & Veins revision & Success & 52 & 175 & 12 & 11 \\
\hline 25 & M & 39 & IVd & $\begin{array}{l}\text { A: } 1 \text { Graft } \\
\text { V: } 2 \text { Direct } \\
\text { N: Direct ulnar }\end{array}$ & I & Success & 49 & 195 & 10 & 8 \\
\hline 26 & M & 25 & $\mathrm{IVd}$ & $\begin{array}{l}\text { A: } 1 \text { Transfer } \\
\text { V: } 2 \text { Transfers } \\
\text { N: Graft }\end{array}$ & 1 & Success & 45 & 180 & 15 & 11 \\
\hline 27 & $\mathrm{M}$ & 36 & $\mathrm{IVd}$ & $\begin{array}{l}\text { A: } 1 \text { Graft } \\
\text { V: } 2 \text { Direct } \\
\text { N: Cross }\end{array}$ & 1 & Success & 36 & 180 & 12 & 10 \\
\hline
\end{tabular}

(Continued) 
TABLE 1. Subjects' Characteristics, Type of Injury, Surgical Procedure, and Clinical Outcome (Continued)

\begin{tabular}{|c|c|c|c|c|c|c|c|c|c|c|}
\hline \multirow[b]{2}{*}{ Patient } & \multirow[b]{2}{*}{ Sex } & \multirow[b]{2}{*}{ Age (y) } & \multirow[b]{2}{*}{ Class } & \multirow[b]{2}{*}{ Surgical Procedure } & \multirow[b]{2}{*}{ Complication } & \multirow[b]{2}{*}{ Result } & \multirow{2}{*}{$\begin{array}{l}\text { Follow-Up } \\
\quad(\mathrm{mo})\end{array}$} & \multirow[b]{2}{*}{ TAM } & \multicolumn{2}{|c|}{ Sensibility } \\
\hline & & & & & & & & & $2 \mathrm{sPD}$ & $2 \mathrm{mPD}$ \\
\hline 28 & M & 38 & $\mathrm{IVd}$ & $\begin{array}{l}\text { A: } 1 \text { Transfer } \\
\text { V: } 1 \text { Direct }+1 \text { graft } \\
\text { N: Cross }\end{array}$ & I & Success & 32 & 180 & 12 & 9 \\
\hline 29 & $\mathrm{~F}$ & 21 & $\mathrm{IVd}$ & $\begin{array}{l}\text { A: } 1 \text { Transfer } \\
\text { V: } 2 \text { Transfers } \\
\text { N: Vein graft }\end{array}$ & 1 & Success & 27 & 195 & 14 & 13 \\
\hline 30 & $\mathrm{~F}$ & 14 & $\mathrm{IVd}$ & $\begin{array}{l}\text { A: } 1 \text { Transfer } \\
\text { V: } 2 \text { Direct } \\
\text { N: Direct ulnar }\end{array}$ & 1 & Success & 21 & 195 & 9 & 8 \\
\hline 31 & $\mathrm{M}$ & 45 & $\mathrm{IVd}$ & $\begin{array}{l}\text { A: } 1 \text { Graft } \\
\text { V: } 1 \text { Direct }+1 \text { graft } \\
\text { N: Cross }\end{array}$ & I & Success & 19 & 165 & 13 & 10 \\
\hline 32 & M & 40 & $\mathrm{IVd}$ & $\begin{array}{l}\text { A: } 1 \text { Transfer } \\
\text { V: } 2 \text { Grafts } \\
\text { N: Vein graft }\end{array}$ & I & Success & 18 & 175 & 15 & 14 \\
\hline 33 & M & 37 & $\mathrm{IVd}$ & $\begin{array}{l}\text { A: } 1 \text { Transfer } \\
\text { V: } 1 \text { Direct }+1 \text { graft } \\
\text { N: Cross }\end{array}$ & 1 & Success & 12 & 180 & 14 & 12 \\
\hline
\end{tabular}

A Graft, vein graft for artery; A Transfer, transfer of the collateral ulnar digital artery from the middle finger; N Cross, proximal radial nerve to distal ulnar nerve suture; N Direct, direct ulnar or radial nerve suture; N Graft, nerve reconstruction with graft from the contralateral digital nerve; $\mathrm{N}$ No repair, no nerve repair; $\mathrm{N}$ Vein graft, nerve reconstruction with vein graft; $2 \mathrm{mPD}=$ moving 2-point discrimination test; $2 \mathrm{sPD}=$ static 2-point discrimination test; TAM, total arc of motion of metacarpophalangeal, proximal interphalangeal, and distal interphalangeal joints; V Direct, direct suture of a vein; V Graft, vein graft for vein; V Transfer, transfer of a dorsal vein from the dorsum of the middle finger.

patients were discharged from the hospital in fewer than 8 days.

Owing to arterial or venous compromise, 6 cases required reoperation between 2 and 8 days after replantation. Despite our efforts, 4 cases failed. One amputation was done at a level that allowed primary closure, and 3 patients underwent ray resections.

The 29 successful cases were tracked over an average period of 89 months (range, 12 mo-20 y). One patient required secondary DIP joint arthrodesis. Outcome analysis included total active motion (TAM) of all 3 joints, sensibility (evaluated using the Weber static 2-point discrimination test and the moving 2-point discrimination test), and cold intolerance.

Data analysis was carried out with the intention-totreat method. ${ }^{14}$ Missing data were estimated according to worst-case scenarios. ${ }^{15}$ In case of normal distribution, independent $t$-test samples were used to define 2-sided probabilities of statistical significance; and in the analyses reporting an F-test $P$ less than 0.05 (variances of 2 samples cannot be assumed to be equal), the $t$-test was used to correct unequal variances (Welch test). When parametric distribution was not respected, the Mann-Whitney test was performed for independent samples.

\section{RESULTS}

The average TAM of the reconstructed finger was $185^{\circ}$ (range, $\left.160^{\circ}-240^{\circ}\right)$. In class IVi (5 cases), the average TAM was $206^{\circ}$ (range, $185^{\circ}-240^{\circ}$ ), whereas in class IVd (24 cases), the average TAM was $180^{\circ}$ (range, $160^{\circ}-195^{\circ}$ ) (Table 2).

Sensibility evaluated by static 2-point discrimination varied from 9 to $15 \mathrm{~mm}$ (average, $12 \mathrm{~mm}$ ) and by moving 2-point discrimination it varied from 8 to 15 $\mathrm{mm}$ (average, $10 \mathrm{~mm}$ ). The test was carried out on the side corresponding to the repaired nerve. Five patients complained of cold intolerance (cases nos. 3, 22, 26, 29 , and 33).

Table 2 compares the clinical outcome between class IVi and class IVd and between the cases treated with arterial transfers and vein grafts.

When applying the intention-to-treat method, there were no significant differences. However, it is notewor- 


\begin{tabular}{|c|c|c|c|}
\hline & $\begin{array}{c}\text { Class IVi } \\
\mathrm{n}=5(0 \text { failures })\end{array}$ & $\begin{aligned} & \text { Class IVd } \\
\mathrm{n}= & 28(4 \text { failures })\end{aligned}$ & \\
\hline & Mean (SD) & Mean (SD) & $P$ \\
\hline TAM $\left(^{\circ}\right)$ & 206 (21.6) & $180(11.1)$ & .054 \\
\hline \multicolumn{4}{|c|}{ Sensibility (mm) } \\
\hline $2 \mathrm{sPD}$ & $11.8(2.4)$ & $12.1(2.0)$ & .989 \\
\hline \multirow[t]{2}{*}{$2 \mathrm{mPD}$} & $10.4(2.9)$ & $10.1(1.9)$ & .564 \\
\hline & $\begin{array}{l}\text { Arterial Transfer } \\
\mathrm{n}=18 \text { ( } 1 \text { failure })\end{array}$ & $\begin{array}{c}\text { Vein Graft } \\
\mathrm{n}=15 \text { (3 failures) }\end{array}$ & $P$ \\
\hline TAM $\left(^{\circ}\right)$ & 188 (18.6) & $180(11.0)$ & .087 \\
\hline \multicolumn{4}{|c|}{ Sensibility (mm) } \\
\hline $2 \mathrm{sPD}$ & $12.5(2.2)$ & $11.3(1.7)$ & .063 \\
\hline $2 \mathrm{mPD}$ & $10.7(2.3)$ & $9.4(1.3)$ & .074 \\
\hline
\end{tabular}

2mPD, moving 2-point discrimination test; 2sPD, static 2-point discrimination test; TAM, total active movement.

thy that the best results were obtained in class IVi (TAM) and in the cases that received arterial transfers (TAM and sensibility).

\section{DISCUSSION}

Since the early 1990s, many authors ${ }^{4-7,16,17}$ have reported poor outcomes when treating complete ring avulsion amputations. Recent studies have presented the possibility to obtain more satisfactory functional recovery. ${ }^{18-23}$

It is commonly agreed that amputations at the DIP joint and at the middle phalanx (Class IVd) are candidates for replantation when there is an intact PIP joint with a functional FDS tendon. ${ }^{10,12,18,20,21-24}$

Careful evaluation is necessary in cases of complete amputations proximal to the FDS tendon insertion when the PIP joint is damaged or if the proximal phalanx is fractured (class IVp). Many authors ${ }^{1,4,6,7,11,12,17,18,21-26}$ choose not to attempt replantation when the ring avulsion amputations occur proximal to the FDS insertion. In the 6 cases reported since $1994,,^{23,25,27,28}$ only 1 patient ${ }^{27}$ achieved acceptable functional results.

Patients with complete degloving injuries are not usually considered as candidates for microsurgical treatment; however, this approach is changing. ${ }^{12,20,23,29-32} \mathrm{We}$ have successfully replanted 5 cases of class IVi injuries, which are technically more demanding than class IVd amputations $^{4,8,29}$ (Fig. 1). The results of our class IVi patients (Table 2) suggest that an attempt to save the degloved ring finger should be made.

When the degloved skin is not replantable, ray resection is the best option. ${ }^{33}$ Amputation (preserving the MCP joint) should be considered for patients with manual jobs. ${ }^{26}$ Other surgical solutions are for patients who insist on keeping the severely damaged finger. ${ }^{33-40}$

When replanting, it is crucial to perform an extensive debridement of the damaged artery ${ }^{18}$ as introduced by Weeks and Young ${ }^{41}$ and now widely used. ${ }^{12,20-24}$ The debridement of the vascular structures often leads to large artery and vein defects. ${ }^{18}$ The use of long vein grafts is the most popular technique to restore the arterial flow. ${ }^{1,4-6,11,18,19,21-25,28,41-43}$ We employed this in 15 cases. In our experience, it was not always possible to perform a perfect anastomosis between a smalldiameter digital artery and a large-diameter vein graft. ${ }^{18,21}$ We opted for vein grafts when the digital artery of the ring finger was found in acceptable condition after debridement at the middle phalanx level. When the artery was found to be healthy only more distally, we preferred to use an artery transfer technique. This solution avoided the vessel size discrepancy occurring when the vein graft was needed from the MCP joint level to the DIP joint level. We also chose artery transfer instead of vein graft when the artery proximal to the injury had an uncertain pulse. 
A
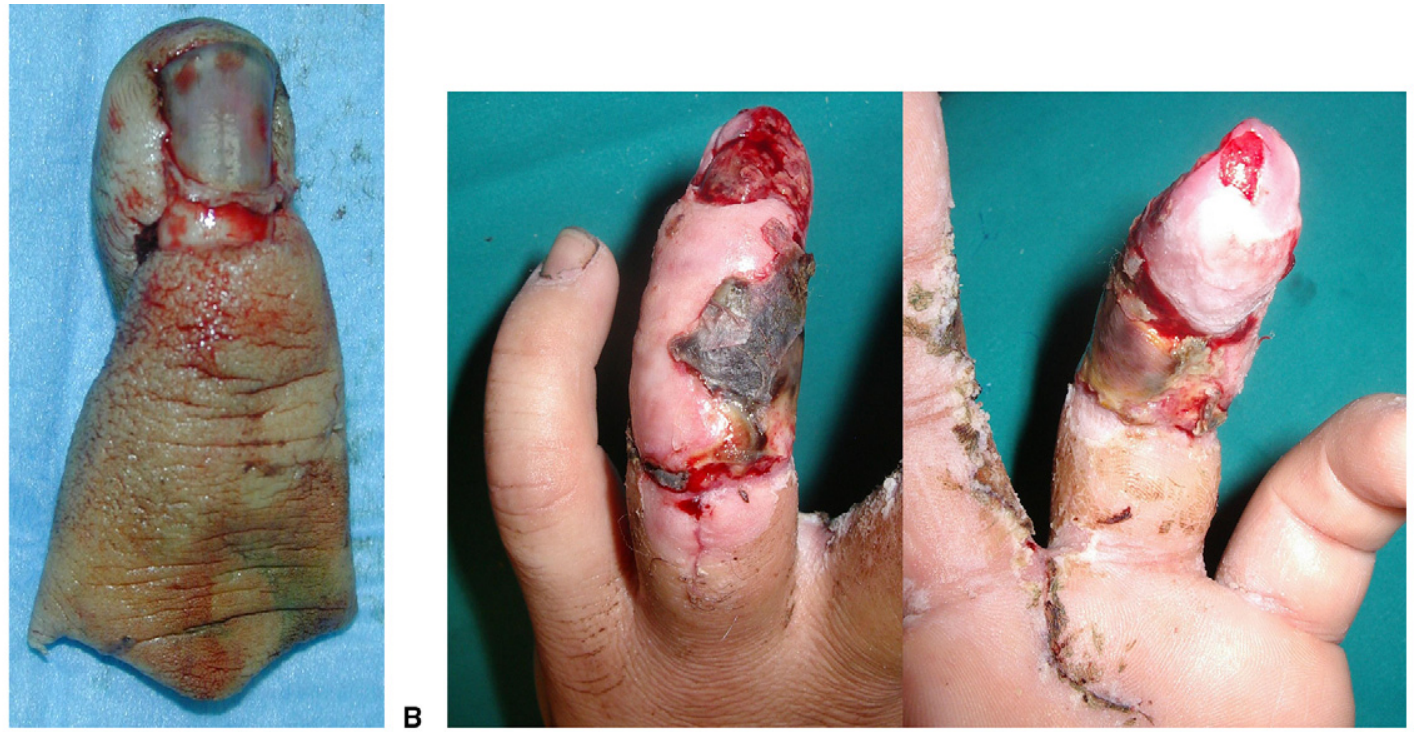

C
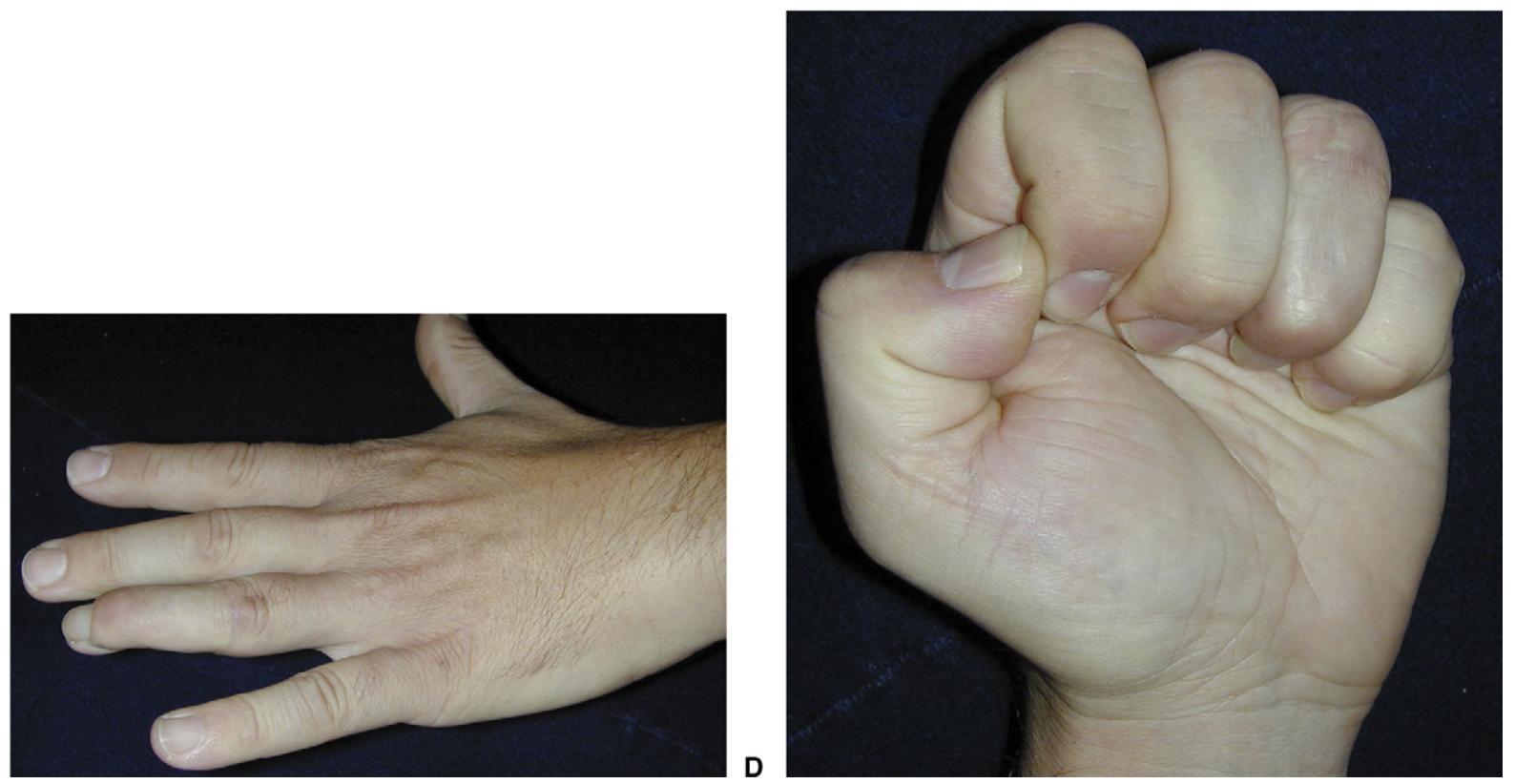

FIGURE 1: Case no. 5. A Class IVi injury. B Skin at 15 days after surgery with eventual healing. C, D Final result.

In 18 patients, we transferred the ulnar artery from the DIP joint of the middle finger to provide arterial inflow. This technique guaranteed long vessel length $^{4,45}$ and allowed for a vascular suture in the distal phalangeal pulp of the ring finger. ${ }^{46,47}$ It also shortened the operative time by reducing the number of anastomoses and decreases the vessel size discrepancy. $^{20,23,27}$

For these reasons, in most cases artery transfer represents our preferred method to provide blood flow in complete ring avulsion amputations.

None of the study patients treated with artery transfer experienced cold intolerance or diminished function of the digit as reported by the majority of the au- thors. ${ }^{12,20,23,27,44-47}$ Only a few papers (without reporting cases) do support this procedure. ${ }^{18,28,48}$

The only unsuccessful case (no. 12) of artery transfer experienced a diffuse arterial vasospasm during surgery. Currently, we routinely irrigate the surgical field with $10 \%$ lidocaine to prevent this.

We used various techniques to restore venous drainage, including direct venous anastomosis, vein grafts, and veins transfer.

Some authors ${ }^{11,24,42,49-52}$ suggest use of venous flaps to restore the skin and venous flow simultaneously. Instead, our experience was similar to that of others ${ }^{18,20,21}$ who suture the dorsal skin loosely to avoid tension. Skin grafts are employed to cover small skin defects. 
A
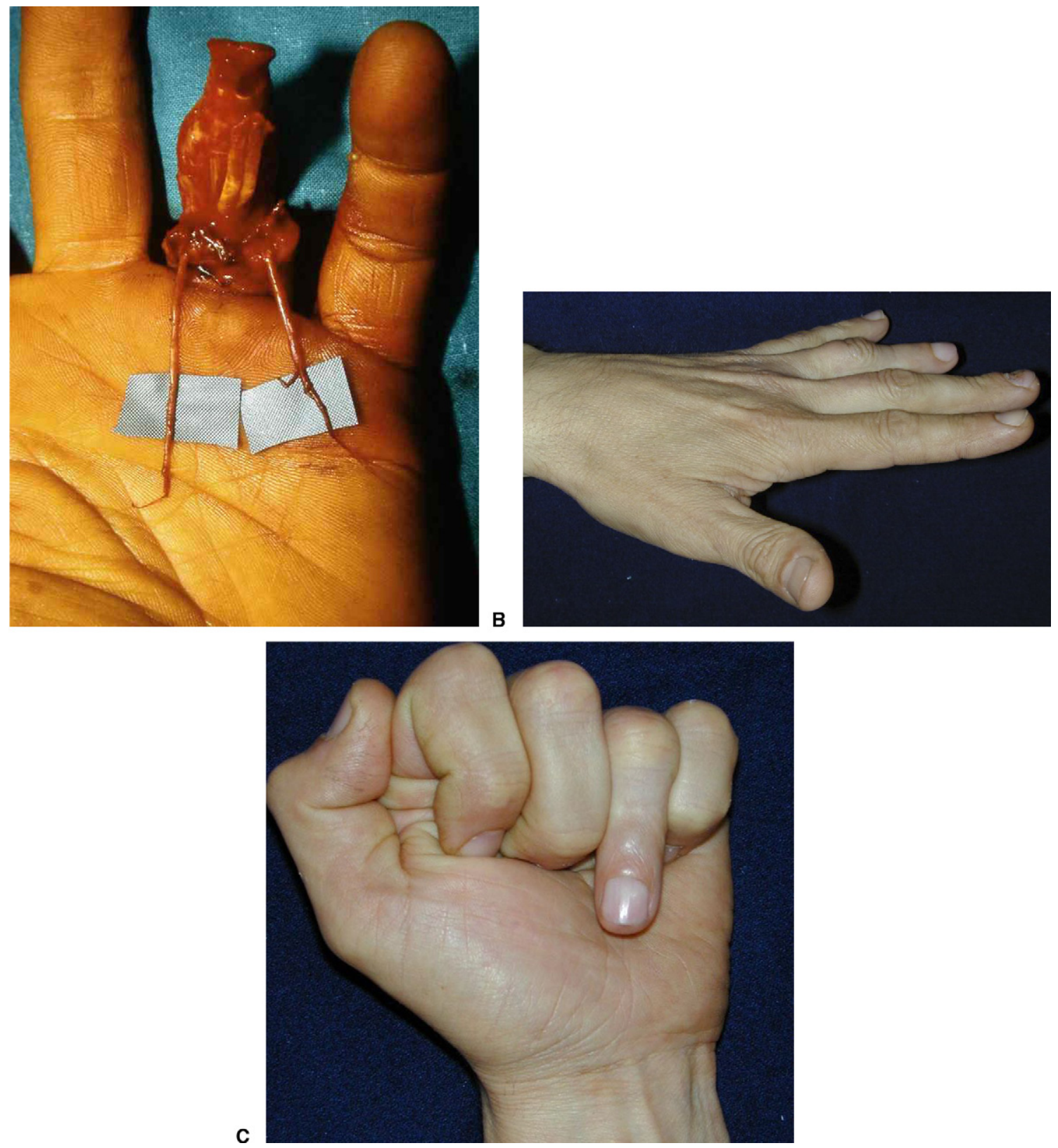

FIGURE 2: Case no. 3. A Class IVd injury with fracture at the middle phalanx and severe avulsion of both digital nerves. B, C Final result with evident lack of flexion of the distal interphalangeal joint.

Small areas of skin necrosis frequently located on the dorsal surface of the finger may arise between 10 and 15 days after replantation, especially in cases characterized by severe skin injuries. At that time, the vascular condition of the finger is generally stable. The healing of the skin usually occurs spontaneously, and therefore, surgery is unnecessary (Fig. 1B).

We repaired only 1 artery and 2 veins despite the recommendation to suture 2 arteries and 3 veins. ${ }^{4,6,11}$ In our experience, 1 artery was nearly always sufficient. $^{18,21,23-25}$ If 2 arteries are sutured, more veins are needed to maintain circulation equilibrium. The survival rate remains the same when reconstructing 2 or more veins. ${ }^{51}$

When it was impossible to suture directly the damaged digital nerves, a cross suture between the proximal radial digital nerve and the distal ulnar nerve was used. The other techniques (contralateral nerve grafts or vein grafts) were used as a second option. Independent of the technique used, the final outcome was poor because of the extensive damage to the avulsed nerve (Fig. 2). Our sensory recovery results (Table 3 ) were slightly better than those published by others. ${ }^{18,21-23}$ 
TABLE 3. Complete Ring Amputations in the Literature: Survival Rate, Average Total Active Movement, Average Sensibility, and Percentage of Success

Study

Cases Treated (n) Survival Cases (n) Success $(\%)$

TAM Average $\left(^{\circ}\right) \quad$ Sensibility 2sPD (Average)

$\begin{array}{lr}\text { Urbaniak et al, } 1981^{4} & 7 \\ \text { Tsai et al, } 1984^{6} & 7 \\ \text { Beris et al, } 1994^{25} & 13 \\ \text { Kay et al, } 1989^{11} & 27 \\ \text { van der Horst et al, 1989 } & 9 \\ \text { Akyurek et al, } 2002^{18} & 7 \\ \text { Adani et al, } 2003^{20} & 7 \\ \text { Sanmartin et al, } 2004^{51} & 28 \\ \text { Ozkan et al, 2006 } & 3 \\ \text { Hyza et al, 2007 } & 6 \\ \text { Ozaksar et al, } 2012^{23} & 37 \\ \text { Present study } & 33\end{array}$

3

43

145

12

6

$8 \quad 61$

86

163

NR

61

NR

9.7

$16 \quad 59$

$6 \quad 67$

$7 \quad 100$

$91.5 \pm 21.6$

NR

7 NR

NR

$6 \quad 86$

194

7.8

$86 \quad 200 \quad 13.8$

$22 \quad 79$

173

NR

$3 \quad 100$

190

9

$6 \quad 100$

195

8.6

$31-84$

172

9.4

$29 \quad 88$

189

12

2mPD, moving 2-point discrimination test; NR, not reported; 2sPD, static 2-point discrimination test; TAM, total active movement.

More cases with vein and nerve grafts would have been necessary to allow for a proper comparison between the various types of treatment. None of the patients developed painful neuromas. Only 5 patients reported cold intolerance by the end of the lengthy follow-up period. Cold intolerance regressed slowly over time. In 1 case (no. 3), it persisted at 12-year follow-up.

The functional results were influenced by the associated bony and tendon injuries. Overall average TAM was $185^{\circ}$. There was a minor difference between class IVi (average TAM, $206^{\circ}$ ) and class IVd (average TAM, $180^{\circ}$ ). These differences were due to the integrity of the joints and tendons in class IVi and support the importance of early rehabilitation. ${ }^{8,21}$

\section{REFERENCES}

1. Brooks B, Buntic RF, Kind GM, Schott K, Buncke GM, Buncke HJ. Ring avulsion: injury pattern, treatment, and outcome. Clin Plast Surg. 2007;34(2):187-195.

2. Kupfer DM, Eaton C, Swanson S, McCarter MK, Gilbert WL. Ring avulsion injuries: a biomechanical study. J Hand Surg Am. 1999; 24(6):1249-1253.

3. Mitchell GM, Morrison WA, Papadopoulos A, O'Brien BM. A study of the extent and pathology of experimental avulsion injury in rabbit arteries and veins. Br J Plast Surg. 1985;38(2):278-287.

4. Urbaniak JR, Evans JP, Bright DS. Microvascular management of ring avulsion injuries. J Hand Surg Am. 1981;6(1):25-30.

5. Nissenbaum M. Class IIA ring avulsion injuries: an absolute indication for microvascular repair. J Hand Surg Am. 1984;9(6):810815.

6. Tsai TM, Manstein C, DuBou R, Wolff TW, Kutz JE, Kleinert HE. Primary microsurgical repair of ring avulsion amputation injuries. J Hand Surg Am. 1984;9(1):68-72.

7. Pederson WC. Replantation. Plast Reconstr Surg. 2001;107(3):823841.
8. Chung KC. Invited discussion: long-term results of replantation for complete ring avulsion amputations. Ann Plast Surg. 2003;51(6): 569.

9. Weil DJ, Wood VE, Frykman GK. A new class of ring avulsion injuries. J Hand Surg Am. 1989;14(4):662-664.

10. Davis Sears E, Chung KC. Replantation of finger avulsion injuries: a systematic review of survival and functional outcomes. $J$ Hand Surg Am. 2011;36(4):686-694.

11. Kay S, Werntz J, Wolff TW. Ring avulsion injuries: classification and prognosis. J Hand Surg Am. 1989;14(2 Pt 1):204-213.

12. Adani R, Castagnetti C, Busa R, Caroli A. Ring avulsion injuries: microsurgical management. J Reconstr Microsurg. 1996;12(3):189194.

13. Lim BH, Tan BK, Peng YP. Digital replantations including fingertip and ring avulsion. Hand Clin. 2001;17(3):419-431.

14. Newell DJ. Intention-to-treat analysis: implications for quantitative and qualitative research. Int J Epidemiol. 1992;21(5):837-841.

15. Gamble C, Hollis S. Uncertainty method on best-worst case analysis in a binary meta-analysis. J Clin Epidemiol. 2005;58(6):579-588.

16. Hung LK, Leung PC. Salvage of the ring avulsed finger in heavy manual workers. Br J Plast Surg. 1989;42(1):43-45.

17. Urbaniak JR, Roth JH, Nunley JA, Goldner RD, Koman LA. The results of replantation after amputation of a single finger. $J$ Bone J Surg Am. 1985;67(4):611-619.

18. Akyurek M, Safak T, Kecik A. Ring avulsion replantation by extended debridement of the avulsed digital artery and interposition with long venous graft. Ann Plast Surg. 2002;48(6):574-581.

19. Sabapathy R, Venkataramani H, Bharathi R, Sebastin SJ. Replantation of ring avulsion amputations. Indian J Plastic Surg. 2003;36(2): $76-83$.

20. Adani R, Marcoccio I, Castagnetti C, Tarallo L. Long-term results of replantation of complete ring avulsion amputations. Ann Plast Surg. 2003;51(6):564-568.

21. Ozkan O, Ozgentas HE, Safak T, Dogan O. Unique superiority of microsurgical repair technique with its functional and aesthetic outcomes in ring avulsion injuries. J Plast Reconstr Aesthet Surg. 2006;59(5):451-459.

22. Hyza P, Vesely J, Drazan L, Stupka I, Ranno R, Castagnetti F. Primary vein grafting in treatment of ring avulsion injuries. Ann Plast Surg. 2007;59(2):163-167. 
23. Ozaksar K, Toros T, Sugun TS, Kayalar M, Kaplan I, Ada S. Finger replantations after ring avulsion amputations. J Hand Surg Eur. 2012;37(4):329-335.

24. Foucher G. Technique of ring injuries replantation. Plast Reconstr Surg. 1988;81(6):996-997.

25. Beris EA, Soucacos PN, Malizos KN, Xenakis TA. Microsurgical treatment of ring avulsion injuries. Microsurgery. 1994;15(7):459463.

26. Nuzumlali E, Orhun E, Ozturk K, Cepel S, Polatkan S. Results of ray resection and amputation for ring avulsion injuries at the proximal interphalangeal joint. J Hand Surg Br. 2003;28(6):578-581.

27. Cheng SL, Chuang DC, Tung TC, Wei FC. Successful replantation of an avulsed middle finger. Ann Plast Surg. 1998;41(6);662-666.

28. Fejjal N, Belmir R, El Mazouz S, Gharib NE, Abbassi A, Belmahi AM. Finger avulsion injuries. A report of four cases. Indian J Orthop. 2008;42(2);208-211.

29. Sagi A, Ben Meier P. Ring avulsion injuries still serve a great challenge to the surgeon. J Reconstr Microsurg. 1989;5(4):397.

30. Tseng OF, Tsai YC, Wei FC, Staffenberg DA. Replantation of ring avulsion of index, long, and ring fingers. Ann Plast Surg. 1996;36(6): $625-628$.

31. Adani R, Busa R, Castagnetti C, Castagnini L, Caroli A. Replantation of degloved skin of the hand. Plast Reconstr Surg. 1998;101(6): $1544-1551$.

32. Adani R, Busa R, Tarallo L, Castagnetti C. Update on replantation of degloved skin of the hand. Plastic Reconstr Surg. 2004;114(5): $1228-1232$

33. Adani R, Tarallo L. Letter regarding "salvage of complete degloved digits with reversed vascularised pedicle forearm flap: a new technique." J Hand Surg Am. 2012;37(10):2197.

34. Khouri RK, Diehl GJ. Salvage in a case of ring avulsion injury with an immediate second-toe wrap-around flap. J Hand Surg Am. 1992; 17(4):714-718.

35. Sica A, Dubert T. Skin graft and cross finger flap for salvage reconstruction of ring finger avulsion. Chir Main. 2005;24(5):246250 .

36. Munnoch DA, Stevenson JH. Primary reconstruction of a degloved middle finger with a temporoparietal free flap. J Hand Surg Br. 1999;24(4):443-444.

37. Hashem AM. Salvage of degloved digits with heterodigital flaps and full thickness skin graft. Ann Plast Surg. 2010;64(2):155-158.
38. Abo-hashem Azab Moosa A. Double cross-finger flaps. A novel technique for management of ring avulsion injuries. Ann Plast Surg. 2010;64(4):409-411.

39. Azzena B, Amabile A, Tiengo C. Use of acellular dermal regeneration template in a complete finger degloving injury: case report. J Hand Surg Am. 2010;35(12):2057-2060.

40. Noaman HH. Salvage of completely degloved digits with reversed vascularised pedicle forearm flap: a new technique. J Hand Surg Am. 2012;37(4):832-836.

41. Weeks PM, Young LV. Revascularization of the skin envelope of a denuded finger. Plast Reconstr Surg. 1982;69(3):527-531.

42. van der Horst CM, Hovious SE, van der Meulen JC. Result of treatment of 48 ring avulsion injuries. Ann Plast Surg. 1989;22(1): 9-13.

43. McDonald AH, Cleland HJ, Leung M, Slattery PJ. Ring avulsion injuries. Aust N Z J Surg. 1999;69(7):514-516.

44. Pho RW, Chacha PB, Yeo KQ. Rerouting vessels and nerves from other digits in replanting an avulsed and degloved thumb. Plast Reconstr Surg. 1979;64(3):330-335.

45. Lobay GW, Moysa GL. Primary neurovascular bundle transfer in the management of avulsed thumbs. J Hand Surg Am. 1981;6(1): 31-34.

46. Castagnetti C, Adani R, Squarzina PB, Caroli A. Transfer of vessels in the management of ring avulsion injury. Scand J Plast Reconstr Hand Surg. 1992;26(3):331-333.

47. Adani R, Castagnetti C, Busa R, Caroli A. Transfer of vessels in the management of thumb and ring avulsion injuries. Ann Acad Med Singapore. 1995;24(4 Suppl):51-57.

48. Molski M. Replantation of fingers and hands after avulsion and crush injuries. J Plast Reconstr Aesthet Surg. 2007;60(7):748-754.

49. Foucher G, Citron N, Merle M, Dury N. Revascularization of ring fingers. Ann Chir Main. 1986;5(3):256-259.

50. Martin DL, Kaplan IB, Kleinert JM. Use of a reverse cross-finger flap as a vascularized vein graft carrier in ring avulsion injuries. $J$ Hand Surg Am. 1990;15(1):155-159.

51. Sanmartin M, Fernandes F, Lajoie AS, Gupta A. Analysis of prognostic factors in ring avulsion injuries. J Hand Surg Am. 2004;29(6): $1028-1037$.

52. Brooks D, Buntic RF, Taylor C. Use of the venous flap for salvage of difficult ring avulsion injuries. Microsurgery. 2008;28(6):397-402. 